\title{
Physicochemical and Nutritional Properties of Varieties of Carrot (Daucus carota) grown in Region of Korhogo, North of Côte d'Ivoire
}

\author{
Coulibaly Lacina Fanlégué ${ }^{1}$, Touré Abdoulaye², Siéné Laopé Ambroise \\ Casimir ${ }^{1}$, Coulibaly Namongo Adama ${ }^{3}$, SORO Yadé Réné ${ }^{4}$
}

\author{
${ }^{1}$ Département de Biologie Végétale, UFR Sciences Biologiques, Université Peleforo Gon Coulibaly, \\ BP 1328 Korhogo, Côte d'Ivoire \\ ${ }^{2}$ Département de Biochimie-Génétique, UFR Sciences Biologiques, Université Peleforo Gon Coulibaly, \\ BP 1328 Korhogo, Côte d'Ivoire \\ ${ }^{3}$ Département de l'Agriculture, Institut de Gestion Agropastorale, Université Peleforo Gon Coulibaly, \\ 01 BP 2486 Abidjan 01, Côte d'Ivoire. \\ ${ }^{4}$ Laboratoire de Biotechnologie, UFR Biosciences, Université Félix Houphouët Boigny, \\ 22 BP 582 Abidjan 22, Côte d'Ivoire \\ Corresponding author Email: tourabdoulaye@yahoo.fr
}

\begin{abstract}
Very popular for its therapeutic and nutritional virtues, culture of carrot (Daucus carota) has developed in temperate zones of Asia and Europe but also in some tropical regions of Africa including Côte d'Ivoire. Agronomic factors, commercial and food requirements require selection of varieties with good nutritional values. In this study, physicochemical properties and nutritional values of four carrot varieties namely Amazonia, Bahia, Madona and Pamela+ were compared after cultivation and harvest in region of Korhogo. Results showed that, Amazonia, the control carrot variety stands out for its acidity and minerals levels. Bahia is the richest variety with high levels of carbohydrate and protein. Madona is the most basic, wettest and fatest carrot. For a long storage, Pamela is most interesting variety. To our knowledge, it is the first time that physicochemical and nutritional parameters of carrot varieties in region of Korhogo have been studied. Future research on these carrot varieties will be studied of their post-harvest conservation, their sensory analysis and their transformation.
\end{abstract}

Keywords-Carrot varieties, Daucus carota, Korhogo, nutritional values, physicochemical properties.

\section{INTRODUCTION}

Carrot (Daucus carota) is a bi-annual herbaceous plant of the Apiaceae family grown for its taproot which is edible fresh or cooked. Developed as a spare and unbranched organ (in loose soil, without obstacle), its root is fleshy, brittle, pigmented (but rarely white) with pleasant taste. Carrot is well known to be rich in carotene, vitamins, proteins, sugar and minerals (Le Clerc, 2001; Reduron, 2007). Carrot is the most important economically species in the Apiaceae family (Rubatzky et al., 1999). It is one of most popular root vegetables grown in the world and most important source of food carotenoids in Western countries, including United States of America (Block, 1994; Torronen et al., 1996). This root vegetable is much consumed in the world because of its nutritional value, its simple and various modes of consumption (Chaux \& Foury, 1994). Carrot is one of the ten most important worldwide vegetable crops for area of production and market value (Simon et al., 2008). In addition to its consumption, carrot is also used as a dye plant to color butter or certain cheeses (Reduron, 2007). There are various colors of carrot (yellow, pink, purple, white, etc.) related to difference in carotenoid content (Clotault et al., 2008; Clotault, 2009). However, orange carrot gradually supplanted all other colors because of its more desirable hue, especially after cooking (Reduron, 2007). This type of carrot is generally the most rich in total carotenoids. The two major carotenoids in orange carrot are $\beta$-carotene and $\alpha$-carotene. It also contains a low proportion of lutein (Nicolle et al., 2004; Clotault, 2009). Many orange cultivars have appeared over time with in particular a diversification of root forms. Thus, the vegetable carrot has diversified into local varieties to respond to crop patterns and various situations (Pitrat \& Foury, 2003; Doré $\&$ Varoquaux, 2006). The food interest of the root of carrot concerns its taste, its color, but also its nutritional characteristics (Aubert \& Bonnet, 1977; Tirilly \& Bourgeois, 1999). Interest is more and more also focused on nutraceutical compounds of this root because of their importance for good health. Indeed carrot is an interesting food for its content of antioxidant compounds, mainly anthocyanins or chlorogenic acid and carotenoids (Sun et 
al., 2009). $\beta$-carotene or provitamin $\mathrm{A}$ is the carotenoid which is transformed by human metabolism into vitamin $\mathrm{A}$ (Dreosti, 1993; Lecomte, 2013). The consumption of carrot contributes to a healthy and balanced diet (Shankara et al., 2005). Very popular for its therapeutic and nutritional virtues, culture of carrot has developed in temperate zones of Asia and Europe but also in some tropical regions of Africa including Côte d'Ivoire. In addition to agronomic factors (precocity, high yields, pest resistance), commercial and food requirements require the selection of varieties with good nutritional values.

Objective of this study is to compare physicochemical and nutritional properties of four hybrid varieties of carrots, namely Amazonia, Bahia, Pamela+ and Madona, grown in northern Côte d'Ivoire.

\subsection{Zone of study}

\section{MATERIALS AND METHODS}

Study was conducted in commune of Korhogo, located in northern Côte d'Ivoire. Geographic coordinates of this area are $9^{\circ} 26^{\prime}$ North Longitude and $5^{\circ} 38^{\prime}$ 'West Latitude. Climate is Sudanese, very hot, very dry and characterized by an alternation of two main seasons: the dry season and rainy season. Dry season runs from November to April and rainy season from May to October. Maximum rainfall is achieved in August and September and varies between 255 and $267 \mathrm{~mm}$, with an annual average of about $1200 \mathrm{~mm}$. The dry season of this climate is marked by harmattan which is a hot and dry wind from Northeast whose peak is between December and January. Average temperatures vary between from 24 to $33{ }^{\circ} \mathrm{C}$ with a monthly average humidity of $20 \%$. Soil profile of region is characterized by the very large predominance of ferralitic soils. In general, these soils have very variable saturation levels between 20 and $50 \%$. Relief is generally flat and dotted with inselbergs. Average annual duration of sunstroke in this geographic zone is 2500 hours. Monthly average is about 205 hours in the dry season compared to nearly 140 hours during months of July and August who are the most watered (Koffie \& Yéo, 2016).

\subsection{Plant material}

Plant material is composed of four hybrid varieties of carrot (Daucus carota sub. sp. Sativus), belonging to the Kuroda type. These varieties are known by their vernacular names. Variety namely Amazonia is the most cultivated in the region of Korhogo. It has been used as control in this study because its agronomic characteristics are well known. After 90 to 95 days of cultivation, the pivoting roots of Amazonia can reach 16 to $18 \mathrm{~cm}$ long (Technisem, 2017).

\subsection{Conduct of experimentation}

Test was conducted using a completely randomized block device of Fisher with four (4) treatments and four (4) repetitions. Study consisted of sixteen (16) elementary plots. Each sub-plot consisted of seventy-two (72) plants, transplanted on six (6) lines according to spacings of 25 $\mathrm{cm} \times 8 \mathrm{~cm}(25 \mathrm{~cm}$ between two lines and $8 \mathrm{~cm}$ between two plants in the same line). Each elementary plots had an area of $2 \mathrm{~m}^{2}$ each and the blocks, were respectively separated by a distance of $50 \mathrm{~cm}$ and $80 \mathrm{~cm}$. Whole plot consisted of one thousand one hundred and fifty-two (1152) plants on a total area of around $60 \mathrm{~cm}^{2}$. Test was conducted in dry season (off-season period). Two (2) kilograms $(\mathrm{kg})$ of fully decomposed chicken manure were added to each basal plot as background fertilizer two weeks prior to carrot seeding. After sowing, mulching of plots was done to maintain sufficient soil moisture after watering operations. Thinning was done at the stage of appearance from 3 to 5 leaves (22 to 35 days after emergence of plants). Purpose of thinning was to maintain spacing of $8 \mathrm{~cm}$ between plants on same line. Weeding has been regularly carried out to eliminate weeds and ensure good aeration of soil. A first mineral fertilization was carried out on $46^{\text {th }}$ day after sowing with mineral fertilizer NPK (formula: $12-11-18+2.7 \mathrm{MgO}+8 \mathrm{~S}+\mathrm{B}+\mathrm{Fe}+\mathrm{Zn}+\mathrm{Mn}$ ) at rate of $50 \mathrm{~g}$ per elementary plot. A second mineral fertilizer (formula: $15.4 \mathrm{~N}+25.6 \mathrm{CaO}+0.3 \mathrm{~B}$ ) was applied 3 weeks after first amendment of the soil, at a rate of $30 \mathrm{~g}$ per elementary plot. Preventive treatments against insects were applied on the plots once a week from 8 leaves (66 days after emergence of plants) with the product "Cypercal" provided by Callivoire (Côte d'Ivoire) at rate of $1 \mathrm{l} / \mathrm{ha}$. This dose is equivalent to a mixture of $6.6 \mathrm{ml}$ of the product and 2.51 of water per elementary parcel. The carrot roots were harvested from $90^{\text {th }}$ day after emergence of plants (3 months and week after sowing).

\subsection{Analytical procedures}

Root samples of four (4) varieties of carrots from experimental test were cleaned in the laboratory to remove foreign elements. These roots were crushed using an electric grinder (Clatronic KM 3648, France) with perforated disk of $10 \mu \mathrm{m}$ of diameter. The grind of each variety of carrot was put carefully in closed bottle and stored in refrigerator at $4{ }^{\circ} \mathrm{C}$ before their use for biochemical and nutritional analyzes.

Physicochemical parameters of samples of each variety of carrot were determined according to the official methods of analysis of Association of Official Analytical Chemists (AOAC, 1990). Moisture content of samples was determined by desiccation using the method of De Knegt \& Brink (1998). A clean platinum dish was dried in an oven (Memmert UN 110, Allemagne) and cooled in a 
desiccator and weighed. From each sample, $10 \mathrm{~g}$ was weighed and spread on the dish. Then the dish containing the sample was weighed. It was then transferred into the air oven at $105{ }^{\circ} \mathrm{C}$ to dry until a constant weight was obtained and the loss in mass was determined. In order to obtain the $\mathrm{pH}$ of the samples, $10 \mathrm{~g}$ of each sample was weighed and suspended in $10 \mathrm{ml}$ of distilled water. The $\mathrm{pH}$ was determined with a digital pH-meter (Hanna EUTECH INSTRUMENTS PH 700, Espagne). Titratable acidity of samples was determined by titration with $0.1 \mathrm{~N}$ of sodium hydroxide solution, using phenolphthalein as indicator. The results are calculated in citric acid equivalent and expressed in $\mathrm{g} / \mathrm{l}$ of acid (Abbas \& Khoudi, 2016).

For nutritional parameters, carbohydrate was determined according to phenol sulfuric acid method (Dubois et al., 1956). A standard curve was obtained using the following concentration of sucrose in $(\mathrm{mg} / \mathrm{ml}) 2.52 .0$, $1.25,1.0,0.5 \mathrm{~g}$ of each sample with $9 \mathrm{ml}$ of distillated water was measured into test-tube. $2 \mathrm{ml}$ of phenol solution (1\%) and $1 \mathrm{ml}$ of concentrated $\mathrm{H} 2 \mathrm{SO} 4$ solution were added. This was shaken for $15 \mathrm{~min}$ and boiled for $30 \mathrm{~min}$. It was then allowed to cool. The absorbance was then read off a spectrophotometer (UV-Visible, type 7315) at 700 $\mathrm{nm}$. The sugar concentration was then obtained by extrapolation from the standard curve. Protein was analyzed by the Microkjedhal nitrogen method, using a conversion factor of 6.25 according method described by Hamon et al. (1990). Lipid content was obtained by Soxhlet extraction as described by Lecoq (1965). Ash was determined according to the standard methods described by the Association of Official Analytical Chemists (AOAC, 1990). Five (5) $g$ of sample of carrot crushed was ashed in a muffle furnace Pyrolabo, France) at $550{ }^{\circ} \mathrm{C}$. Percentage of residues obtained after incineration corresponds to ash content.

\subsection{Statistical analyzes}

Data collected in triplicates from these studies were analyzed using Statistical Analysis Software XLSTAT version 7.5.3. Data were expressed as means, giving relative standard deviations. The Student Newman Keuls test (SNK) with 5\% of signification was used to discriminate the means. Correlations and a principal component analysis (PCA) were realized in order to detect differences that discriminate the carrot varieties.

\section{RESULTS AND DISCUSSION}

Results obtained for physicochemical and nutritional parameters of four carrot varieties are presented in Table 1. Variance analysis for each parameter studied revealed significant differences between four carrot varieties according to SNK test at $5 \%$.

\subsection{Physicochemical properties}

Moisture content of carrot varieties varies from 86.3 to $87.2 \%$ (SNK, 5\%). Analysis of these data shows that carrot Palema+ is a variety which has the highest moisture content with $87.2 \%$ compared to other varieties $(86.96-86.21 \%)$. These values revealed that carrot is a wet root. Moreover, these values corroborate those of other authors which showed that moisture content of carrots varies from 86 to 89\% (Gopalan et al., 1991; Arscot \& Tanumihardio, 2010). However, studies of Cohen et al. (2009) showed that moisture content of carrot is $89 \%$, while those of Holland et al. (1991) reported a value of $88.80 \%$.

Varieties of carrots analyzed are $\mathrm{pH}$ values ranging from 6.51 to 6.60 . There are slightly acidic according to $\mathrm{pH}$ scale of the products (Anonyme, 2009). Analysis of variance (SNK, 5\%) revealed significant difference between these $\mathrm{pH}$. Control variety Amazonia and variety Pamela+ have approximate $\mathrm{pH}$ values of 6.51 and 6.47 respectively. These values are significantly lower than those of Bahia and Madona varieties who are also neighbors with respectively $\mathrm{pH}$ of 6.63 and 6.60. These results are almost similar to those of Abbas and Khoudi (2016) who reported a $\mathrm{pH}$ value of 6.53 for carrot puree. The studies of Argha and Gavin (2016) revealed however average value of $\mathrm{pH}$ of the carrot between 4.9 and 5.2. Indeed, according to Anonyme (2009), $\mathrm{pH}$ of some products may vary with varietal characteristics, growing conditions and others factors.

For titratable acidity, Analysis of variance showed significant difference between varieties of carrot studied. The highest acidity has been observed in control variety Amazonia with $0.192 \mathrm{~g} / \mathrm{l}$ while Bahia is the least acidic variety with $0.156 \mathrm{~g} / \mathrm{l}$. The other two varieties, Madona and Pamela+ presented intermediary values with respectively acidities of 0.169 and $0.171 \mathrm{~g} / \mathrm{l}$. However, studies of Abbas and Khoudi (2016) on carrot puree reported titratable acidity of $0.2 \mathrm{~g} / \mathrm{l}$. Result obtained by these authors show that varieties of carrot of our study are slightly acidic and must be pleasant to eat.

\subsection{Nutritional properties}

Carbohydrate contents between 5.62 and $6.71 \%$ are observed with carrot varieties studied. Bahia is carrot variety with highest carbohydrate content $(6.71 \%)$ while control variety gave the lowest $(5.62 \%)$. Madona and Pamela+ varieties showed respective intermediate rates of 6.45 and $6.29 \%$. Our results are quite similar to those of Cohen et al. (2009) who reported a value of $6.7 \%$. However, these rates obtained in our study are lower than those of carrot varieties studied by Arscot and Tanumihardio (2010) with 7\%.

For protein, contents of carrot varieties are ranged between 2.71 and $3.66 \%$. Analysis of variance (SNK, 5\%) 
revealed significant difference between these values. Variety Amazonia, as control showed the lowest protein level with $2.71 \%$, followed by Madona which contains 2.89\%. Varieties Pamela+ and Bahia revealed high proportions of protein with respectively 3.15 and $3.66 \%$. These protein levels are well above those obtained through work on other carrot varieties. These protein levels are well above those obtained by Gopalan et al. (1991), Holland et al. (1991) and Cohen et al. (2009) on others varieties of carrots. The work of all these authors, indicated protein proportions in carrot ranging from $0.7 \%$ to $1.1 \%$.

Lipid contents of varieties of carrot analyzed are between $0.79 \%$ and $0.84 \%$. These values are significantly different according to SNK test at 5\%. Lowest content of lipid is observed with Pamela+ carrot variety $(0.79 \%)$ while variety Bahia showed highest level of $0.84 \%$. Madona and Amazonia varieties presented intermediary and approximate contents of lipid with respectively $0.83 \%$ and $0.82 \%$. Lipid contents of carrot varieties studied are higher than those of Gopalan et al. (1991), Holland et al. (1991) and Cohen et al. (2009) who respectively obtained lipid levels of $0.2 \%, 0.5 \%$ and $0.3 \%$ with other carrots. These results show that carrots of our study are rich in lipids.

Ash contents of carrots studied varies between $0.89 \%$ and $1.3 \%$. These results showed a significant difference between varieties analyzed according to SNK test at 5\%. Amazonia variety gave highest ash content with value of $1.3 \%$ followed by Madona who showed $1.24 \%$ of ash. The two others carrot (Bahia and Pamela+) presented lowest ash rates with same value $(0.89 \%)$. On average, ash content of carrot studied is similar to that of Gopalan et $a l$. (1991) with a rate of $1.1 \%$.

\subsection{Correlations between parameters}

According to Pearson test, analysis of results revealed significant correlations between some parameters (Table 2). Most significant positive correlations are between moisture and lipids $\left(\mathrm{R}^{2}=0.92\right)$ and lipids and $\mathrm{pH}\left(\mathrm{R}^{2}=\right.$ 0.93). Most negative correlations are between titratable acidity and carbohydrates $\left(\mathrm{R}^{2}=-0.989\right)$.

\subsection{Discrimination of carrot varieties}

Two axes F1 and F2, allowed to express $95.71 \%$ of variability of observations (Table 3 and Fig. 1). Axis 1 (F1) contributed to $58.67 \%$ of observed variance and axis 2 (F2) to $37.03 \%$. The parameters of carrot varieties studied which have best express on F1 axis are titratable acidity level (which is positively correlated with it), $\mathrm{pH}$, carbohydrate and protein contents (negatively correlated to this axis). For second axis (F2), lipid content, ash and moisture levels are variables positively correlated. The two main axes F1 and F2 described four quarters of plans. Top right quarter above $\mathrm{F} 1$ axis and right of $\mathrm{F} 2$ axis, containing Amazonia variety. Upper left quarter of plan, above F1 axis and to left of F2 axis with Madona variety. Right lower quadrant, below F1 axis and to right of F2 axis with Pamela+ variety. Lower left quarter of plan which is located below $\mathrm{F} 1$ axis and to left of F2 axis including Bahia variety.

Distribution of variables in overall plan constituted by axes F1 and F2 was following. Ash level and titratable acidity are the two variables which appear in top right quarter of plan. $\mathrm{pH}$, moisture and lipid contents are located in upper left quarter of plan. Carbohydrate and protein levels are shown in lower left quarter plan. No variable do not appears in lower right quarter of plan.

So Bahia variety is characterized by carbohydrate and proteins contents while Amazonia, a control variety is marked by ash and titratable acidity levels. $\mathrm{pH}$, lipid and moisture levels were most important determinants of Madona variety. No parameters are characteristic of Pamela+ variety.

\section{CONCLUSION}

This study showed a significant variation in physicochemical and nutritional characteristics of the four carrot varieties grown in region of Korhogo. Investigations closed that, Amazonia, the control carrot variety stands out for its acidity and minerals levels. Nutritionally, Bahia is the richest variety with high levels of carbohydrate and protein. Madona is the most basic, wettest and fatest carrot. For a long storage, Pamela is most interesting variety. To our knowledge, it is the first time that physicochemical and nutritional parameters of carrot varieties in region of Korhogo have been studied. Future research on these carrot varieties will be study of their post-harvest conservation, their sensory analysis and their transformation. These studies will provide scientific data but also advice carrot varieties meeting requirements of growers and consumers in this region.

\section{REFERENCES}

[1] AOAC (1990). Official methods of analysis. Association of Official Analytical Chemists Ed., Washington DC. 684p.

[2] Abbas S. \& Khoudi A. (2016). Essai de formulation d'une boisson à base de fruits (orange, citron et pomme) et légumes (concombre et carotte) au niveau de NCA Rouïba. Mémoire de Master, Université M'Hamed Bougara Boumerdes, République Algérienne Démocratique et Populaire, 68p.

[3] Anonyme (2009). Mannuel d'inspection des produits.24p. Retrieved from http://www.inspection.gc.ca/DAM/DAM-food- 
aliments/STAGING/text/processed_manual_chapter5_ 1386787438167_fra.pdf.

[4] Aubert S. \& Bonnet A. (1977). Intérêt alimentaire des Ombellifères - Exemple de la carotte. In : CAUWET-MARC A.-M. \& CARBONNIER J. (eds). Les Ombellifères - Contributions pluridisciplinaires à la systématique: 809-822. Actes du 2e symposium international sur les Ombellifères, 18 mai 1977, Perpignan, France.

[5] Arqha, Gavin F. (2016). pH des aliments, 8p. Retrieved from

https://www.agridea.ch/fileadmin/thematic/Exploitatio $\mathrm{n} \_$Famille_Diversification/pH_aliments_Lebensmitt el_FR_DE.pdf.

[6] Arscot S.A. \& Tanumihardio S.A. (2010). Carrots of many colors provide basic nutrition and bio-available phytochemicals acting as a functional food. Comprehensive Reviews in Food Science and Food Safety, 9(2): 223-239. DOI: 10.1111/j.15414337.2009.00103.x.

[7] Bloc G. (1994). Source nutritive de caroténoïdes provitamines A dans l'alimentation américaine. American Journal of Epidemiology, 139: 290-293.

[8] Chaux C. \& Foury C. (1994). Productions légumières : Légumes feuilles, tiges, fleurs, racines, bulbes. Tome 2. Editions Technique \& Documentation, Lavoisier, Paris, 639 p.

[9] Clotault J., Peltier D., Berruyer R., Thomas M., Briard M. \& Geoffriau E. (2008). Expression of carotenoid biosynthesis genes during carrot root development. Journal of Experimental Botany, 59: 3563-3573.

[10] Clotault J. (2009). Impact de la sélection sur l'expression et la variabilité de séquences de gènes de la voie de biosynthèse des caroténoïdes chez la carotte cultivée. Thèse de doctorat. Université d'Angers, Angers, $183 \mathrm{p}$.

[11] Cohen J. H., Sánchez N. D. M., Montiel-ishinoet F. D. (2009). Chapulines et choix alimentaires dans les zones rurales d'Oaxaca. Gastronomica: Le Journal de l'Alimentation et de la Culture, 9 (1): 61-65. Retrieved from http://dx.doi.org/10.1525/gfc.2009.9.1.61

[12] De Knegt R.J. \& Brink H.V.D. (1998). Improvement of the drying oven method for the Determination of the Moisture Content of Milk Powder. International Dairy Journal, 8: 733-738.

[13] Dore C. \& Varoquaux F. (2006). Histoire et amélioration de cinquante plantes cultivées. Éditions Quae, Versailles, $844 \mathrm{p}$.

[14] Dreosti I. E. (1993). Les vitamines A, C, E et le bêta-carotène comme facteurs protecteurs de certains cancers. Asie Pacific Journal of Clinical Nutrition. 2 : $5-21$

[15] Dubois M., Gilles K.A., Hamilton J.K., Roben F.A. \& Smith F. (1956). Colorimetric method for determination of sugar and related substances. Anal. Chem. 28, 350-356.

[16] Gopalan C., Ramasastry B.V., Balasubramanian S.C. (1991). Nutritive value of Indian foods. National Institute of Nutrition, Hyderabad, p 47

[17] Hamon M., Pellerin F., Guenet M. \& Maauzier G. (1990). Abréges chimie analytique. Méthodes spectrales et analyse organique. Tome 3. 2eme édition. Masson. Paris. pp: 232-233.

[18] Holland B., Unwin J.D., Buss D.H. (1991). Vegetables, herbs and spices: Fifth supplement to McCance and Widdowson's. The composition of foods, London, 146p.

[19] Koffie B.C.Y. \& Yéo L. (2016). Maraîchage urbain et sécurité sanitaire des aliments à Korhogo. Revue de géographie, d'aménagement régional et de développement des Suds. pp. 176-190. Retrieved from http ://www.regardsuds.org

[20] Le Clerc V. (2001). Etude de la diversité génétique chez la carotte (Daucus carota L.): mise au point de stratégies d'analyse et de régénération des ressources génétiques. Thèse de doctorat. Université d'Angers, Angers, $125 \mathrm{p}$.

[21] Lecomte M. (2013). Analyse des mécanismes de défense de la carotte (Daucus carota) face au champignon pathogène Alternaria dauci, responsable de l'alternariose ou brûlure foliaire. Thèse de doctorat Biologie cellulaire. Université d'Angers, France, p11.

[22] Lecoq R. (1965). Manuel d'analyse alimentaire et d'expertises usuelles. Volume 1. Editions Doin, Paris, France, 938p. Retrieved from http://www.ethnopharmacologia.org/bibliothequeethnopharmacologie/manuel-d-analyses-alimentaireset-d-expertises-usuelles/

[23] Nicolle C., Simon G., Rock E., Amouroux P. \& Remesy C. (2004). Genetic Variability Influences Carotenoid, Vitamin, Phenolic, and Mineral Content in White, Yellow, Purple, Orange, and Dark-Orange Carrot Cultivars. Journal of American Society of Horticulture Sciences. 129: 523-529.

[24] Pitrat M. \& Foury. C. (2003). Histoires de légumes. Des origines à l'orée du XXI ${ }^{\text {ème }}$ siècle. INRA Editions, Paris, France: 410p.

[25] Radhouane L. (2004). Étude de la variabilité morpho-phénologique chez Pennisetum glaucum (L.) R. Br. Plant GeneticResources. Newsletter 138: 18-22.

[26] Reduron J.-P. (2007). Ombellifères de France. Bulletin de la Société Botanique du Centre-Ouest, Tome 2, 564p. 
[27] Rubatzky V. E., Quiros C. F. \& Simon P. W. (1999). Carrots and related vegetable Umbelliferae. CABI, Wallingford, 310p.

[28] Shankara N. Joep V. L., Marja.D. G., Martin. H. et Barbara. V. D. (2005). La culture de la tomate, production transformation et commercialisation. Agrodok, $\mathrm{N}^{\circ} 17$ : 106p.

[29] Simon P. W., Freeman R. E., Vieira J. V., Boiteux L. S., Briard M., Nothnagel T., Michalik B. \& Kwon Y.-S. (2008). Carrot. In: PROHENS J. ET NUEZ F. (eds). Vegetables II - Fabaceae, Liliaceae, Solanaceae, and Umbelliferae. Springer, New York, 327-357.

[30] Sun T., Simon P. W., Tanumihardjo S. A. (2009). Antioxidant Phytochemicals and Antioxidant Capacity of Biofortified Carrots (Daucus carota L.) of Various
Colors. Journal of Agriculture and Food Chemistry. 57: 4142-4147.

[31] Technisem (2017). La variété à haut rendement adaptée aux températures élevées. 1p. Retrieved from https: www.technisem.com.

[32] Tirilly Y. \& Bourgeois C.-M. (1999). Technologie des légumes. Éditions Technique \& Documentation, $558 \mathrm{p}$.

[33] Torronen R., Lehmusaho M., Hakkinen S., Hanninen O., Mykkanen H. (1996). Sérum réponse $\beta$-carotène à la supplémentation en carottes crues, jus de carotte ou $\beta$-carotène purifié chez les femmes non fumeuses en bonne santé. Nutritional Research. 16: 565-575.

TABLES

Table 1: Physicochemical and nutritional parameters of varieties of carrots

$\begin{array}{ccccccc}\begin{array}{c}\text { Moisture } \\ (\%)\end{array} & \text { pH } & \begin{array}{c}\text { Acidity } \\ (\mathrm{g} / \mathrm{l})\end{array} & \begin{array}{c}\text { Carbohydrate } \\ (\%)\end{array} & \begin{array}{c}\text { Protein } \\ (\%)\end{array} & \begin{array}{c}\text { Lipid } \\ (\%)\end{array} & \begin{array}{c}\text { Ash } \\ (\%)\end{array}\end{array}$

\begin{tabular}{|c|c|c|c|c|c|c|c|c|}
\hline \multirow{4}{*}{ 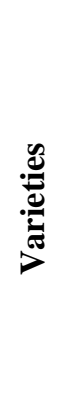 } & Bahia & $86.437^{\mathrm{a}}$ & $6.631^{\mathrm{a}}$ & $0.156^{\mathrm{b}}$ & $6.712^{\mathrm{a}}$ & $3.656^{\mathrm{a}}$ & $0.841^{\mathrm{a}}$ & $0.890^{c}$ \\
\hline & Madona & $86.210^{\mathrm{a}}$ & $6.603^{\mathrm{a}}$ & $0.169^{b}$ & $6.459^{\mathrm{a}}$ & $2.886^{\mathrm{c}}$ & $0.831^{\mathrm{ab}}$ & $1.244^{\mathrm{b}}$ \\
\hline & Pamela+ & $87.200^{\mathrm{b}}$ & $6.472^{\mathrm{b}}$ & $0.171^{\mathrm{b}}$ & $6.293^{\mathrm{a}}$ & $3.146^{\mathrm{b}}$ & $0.786^{\mathrm{b}}$ & $0.888^{\mathrm{c}}$ \\
\hline & Amazonia* & $86.692^{\mathrm{a}}$ & $6.514^{\mathrm{b}}$ & $0.192^{\mathrm{a}}$ & $5.623^{\mathrm{b}}$ & $2.715^{\mathrm{d}}$ & $0.820^{\mathrm{ab}}$ & $1.300^{\mathrm{a}}$ \\
\hline
\end{tabular}

$* \overline{\text { Control }}$

Table.2: Correlation between parameters (Pearson (n)) :

\begin{tabular}{lccccccc}
\hline \multicolumn{1}{c}{ Variables } & Moisture & $\mathbf{p H}$ & Acidity & Carbohydrate & Protein & Lipid & Ash \\
\hline Moisture & $\mathbf{1}$ & 0.8915 & -0.2649 & 0.3237 & 0.0287 & 0.9209 & 0.4521 \\
$\mathrm{pH}$ & 0.8915 & $\mathbf{1}$ & -0.6307 & 0.6464 & 0.4785 & 0.9328 & 0.0087 \\
Acidity & -0.2649 & -0.6307 & $\mathbf{1}$ & $\mathbf{- 0 . 9 8 9 3}$ & -0.8742 & -0.3340 & 0.7189 \\
Carbohydrate & 0.3237 & 0.6464 & $\mathbf{- 0 . 9 8 9 3}$ & $\mathbf{1}$ & 0.7938 & 0.3358 & -0.6426 \\
Protein & 0.0287 & 0.4785 & -0.8742 & 0.7938 & $\mathbf{1}$ & 0.2760 & -0.8552 \\
Lipid & 0.9209 & 0.9328 & -0.3340 & 0.3358 & 0.2760 & $\mathbf{1}$ & 0.2602 \\
Ash & 0.4521 & 0.0087 & 0.7189 & -0.6426 & -0.8552 & 0.2602 & $\mathbf{1}$ \\
\hline
\end{tabular}

Values in bold are most significant correlations. 
Table 3: Values of variables along the axes

\begin{tabular}{lcc}
\hline Parameters & F1 & F2 \\
\hline Moisture & -0.5504 & 0.8275 \\
$\mathrm{pH}$ & -0.8596 & 0.5099 \\
Acidity & 0.9312 & 0.3220 \\
Carbohydrate & -0.9172 & -0.2593 \\
Protein & -0.8281 & -0.4765 \\
Lipid & -0.6524 & 0.7132 \\
Ash & 0.4959 & 0.8605 \\
\hline
\end{tabular}

Biplot (axes F1 and F2 : $95.71 \%$ )

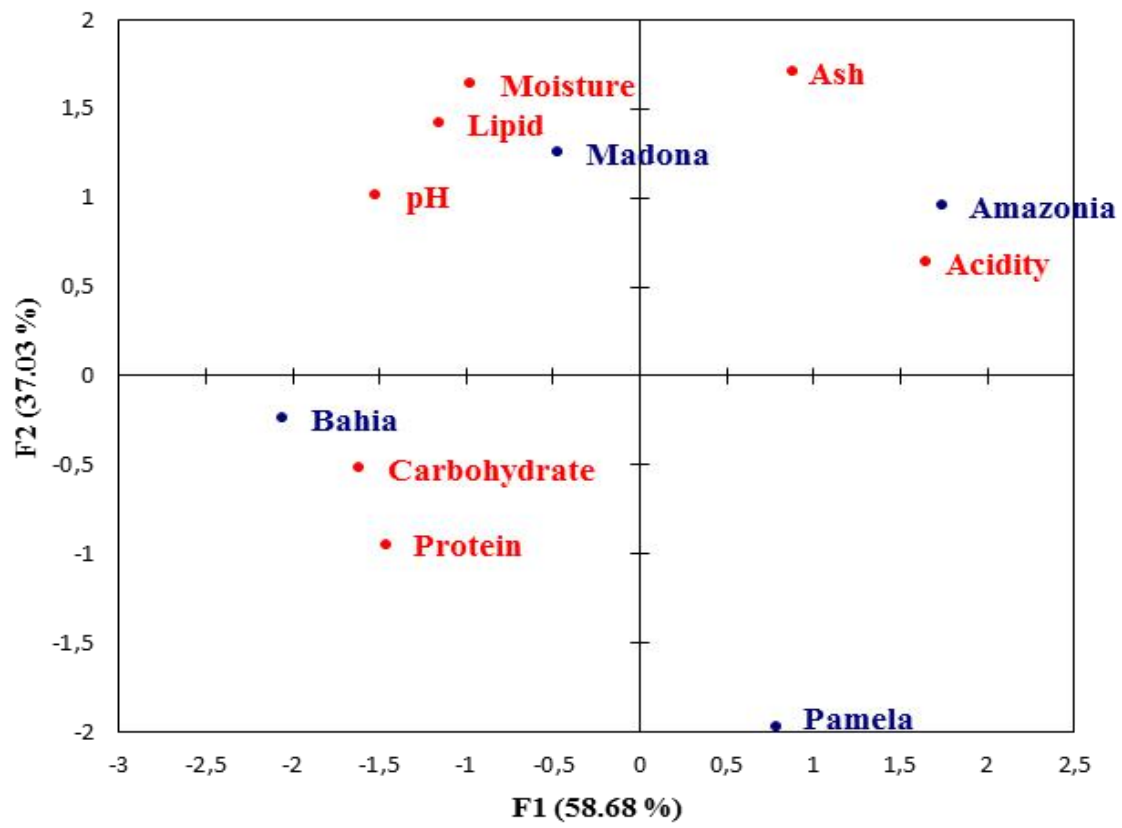

Fig. 1: Plan biplot of varieties of carrots and variable scores (PCA) 